\title{
Identifikasi Struktur Pelat Baja Dengan dan Tanpa Retak yang Berosilasi di dalam Dua Fluida yang Berbeda
}

\author{
Agung Budipriyanto \\ Staft Pengajar Program Diploma D-III Teknik Sipil FTSP - ITS \\ email: agungbp@ce.its.ac.id
}

\begin{abstract}
ABSTRAK
Identifikasi struktur yang berosilasi dalam fluida perlu dilakukan untuk memahami perilaku dinamis struktur dalam interaksinya dangan fluida tersebut. Tulisan ini menyajikan hasil uj i dinamis pelat baja elastis dengan dan tanpa retak di dua macam fluida yaitu udara dan air. Metoda analisis modal eksperimental digunakan untuk uj i ragam lentur struktur baik di udara (tanpa adanya pengaruh rendaman air), terendam sebagian ataupun terendam seluruhnya di dalam air. Paramater modal (frekwensi alamiah, faktor redaman, bentuk ragam), added mass dan added damping factor struktur, yang diperoleh dari hasil studi ini, dibandingkan guna meneliti pengaruh rendaman air serta retak pada struktur. Hasil studi ini menunjukkan bahwa rendaman air dan retak pada struktur berpengaruh cukup signifikan terhadap nilai added damping factor.
\end{abstract}

Kata kunci: Pelat Baja, Retak pada Struktur, Interaksi Struktur dengan Air dan Udara

\section{PENDAHULUAN}

Studi tentang perilaku dinamis struktur yang bertinteraksi dengan udara atau air telah dilakukan secara ekstensif untuk menentukan pengaruh fluida tersebut pada respons struktur utamanya nilai added mass, added (hydrodynamic) damping dan parameter modal (frekwensi alamiah, faktor redaman dan bentuk ragam). Pada beberapa dekade terakhir ini teknik analisis modal eksperimental telah dipakai untuk meneliti perubahan parameter modal akibat kontribusi added mass pada struktur. Sementara itu sejalan dengan banyaknya penelitian tentang monitoring ataupun evaluasi integritas struktur, teknik analisis modal juga digunakan untuk menentukan keberadaan kerusakan pada sebuah struktur.

Identifikasi frekwensi alamiah dan ragam dari struktur berbentuk silinder dilaporkan oleh Randall (1985). Dengan menggunakan akselerometer (sensor pengukur percepatan) yang dipasang sepanjang silinder tersebut, ia membandingkan respons struktur di udara (tanpa pengaruh rendaman air) dan di dalam air. Hasil dari uji tersebut menunjukkan bahwa akibat redaman air, frekwensi alamiah untuk ragam yang pertama dari struktur turun sebesar 50,5\% sedang frekwensi alamiah yang lebih tinggi turun kurang dari $50 \%$ Ragam struktur sulit dibedakan mengingat frekwensi alamiahnya sangat berdekatan. Added mass dari pelat berbentuk bulat yang terendam sebagian dalam air diselidiki oleh Lieb dkk. (1989). Ada dua jenis pelat yang diuji yaitu tanpa lubang dan dengan lubang (perforated plate). Dalam eksperimen yang mereka lakukan, pelat diuji dalam posisi tegak dan respons dinamis dari pelat tersebut diukur dengan akselerometer yang diletakkan di tiga tempat yang berbeda pada pelat. Ketika $99 \%$ dari luasan pelat tesebut terendam air, frekwensi alamiah untuk ragam yang pertama dari pelat tanpa lubang turun sebesar $55.5 \%$ dibandingkan dengan frekwensi pelat di udara (tanpa pengaruh rendaman air). Sedangkan untuk pelat dengan lubang reduksi pada frekwensi alamiah pada ragam yang pertama sebesar 25.9\% Hasil tersebut dapat dimengerti karena kontribusi dari added mass lebih 
besar pada pelat tanpa lubang dibandingkan dengan pelat berlubang. Mereka juga mencatat bahwa korelasi antara added mass yang diperoleh dari eksperimen dan perumusan yang diberikan oleh De Santo (1981) relatif baik. Namun secara umum nilai yang diberikan oleh Lieb dkk. (1985) lebih tinggi dari Randall (1985). Haddara dan Cao (1996) melakukan studi analitis tentang added mass untuk struktur pelat segi empat dengan berbagai kondisi perletakan pada sisi sisinya.

Sebelum melakukan uji terhadap struktur yang lebih kompleks, sebagai langkah awal, penulis telah melakukan uji dinamis eksperimental terhadap struktur pelat baja elastis dalam dua fluida yang berbeda yaitu udara dan air. Pelat diuji pada posisi horizontal dan dijepit pada salah satu ujungnya sedang ujung yang lain bebas. Uji dilakukan terhadap dua kondisi pelat yaitu utuh dan terdapat retak. Tujuan dari uji eksperimental ini adalah untuk mengetahui perubahan perilaku dinamis struktur (khususnya ragam lentur) dengan dan tanpa retak di udara, terendam sebagian dan terendam seluruhnya di dalam air. Parameter modal yang diteliti meliputi frekwensi alamiah (natural frequency), faktor redaman (damping ratio) dan bentuk ragam (mode shape). Berdasarkan hasil eksperimen ini nilai added mass dan added damping factor dari struktur dihitung untuk beberapa kondisi tersebut diatas. Eksperimen ini dilakukan sebagai awal dari rangkaian studi mengenai identifikasi dan monitoring integritas struktur yang berada di darat ataupun terendam dalam air.

\section{DASAR TEORI}

Respons struktur dengan redaman viskus (viscous damping) yang digetarkan oleh eksitasi harmonik, $x(t)$ dapat dituliskan (Maia dan Silva, 1997)

$$
\{x(t)\}=\{X\} e^{i \omega t}
$$

dengan $\{X\}$ adalah amplitudo dari repons dan $\omega$ adalah frekwensi dan $i$ adalah angka imajiner $(\sqrt{-1})$. Substitusi Persamaan (1) pada persamaan gerak diperoleh
$\{X\}=\left([K]-\omega^{2}[M]+i \omega[C]\right)^{-1}\{F\}$

$[K],[M]$, dan $[C]$ masing masing adalah matrix kekakuan, matrix masa, dan matrix redaman, $\{F\}$ adalah vektor gaya. Persamaan (2) dapat dituliskan kembali

$$
\begin{aligned}
& \{X\}=H(\omega)\{F\} \ldots \ldots \ldots \ldots \ldots \ldots \ldots \ldots \ldots \ldots \\
& H(\omega)=\frac{\{X\}}{\{F\}}=\frac{1}{[K]-\omega^{2}[M]+i \omega[C]} .
\end{aligned}
$$

$H(\omega)$ adalah fungsi respons frekwensi. Fungsi respons frekwensi dari struktur yang diperoleh dari eksperimen dapat digunakan untuk mendapatkan parameter modal struktur yang besangkutan.

Dalam menghitung added mass dan added damping, kekakuan struktur diamsumsikan tetap, sehingga untuk ragam ke $\mathrm{n}$ diperoleh hubungan,

$k_{u}=\omega_{n, u}^{2} \cdot m_{u}$

$k_{a}=\omega_{n, u}^{2} \cdot\left(m_{u}+m_{a}\right)$

$m_{u}, m_{a}, k_{a}$ dan $k_{u}$ masing masing adalah masa struktur di udara, masa struktur tambahan di dalam air (added mass), kekakuan struktur dalam air dan di udara. $\omega_{n, a}, \quad \omega_{n, u}$ adalah frekwensi alamiah struktur di dalam air dan di udara pada ragam ke $\mathrm{n}$.

Dari Persamaan (5) dan (6) diatas, ratio antara tambahan masa struktur di dalam air dan udara atau disebut juga added mass factor (AMF) dapat ditulis,

$A M F=\frac{m_{a}}{m_{u}}=\frac{\omega_{n, u}^{2}}{\omega_{n, a}^{2}}-1$

Sedangkan redaman struktur di dalam air dan di udara untuk ragam ke $\mathrm{n}$ adalah

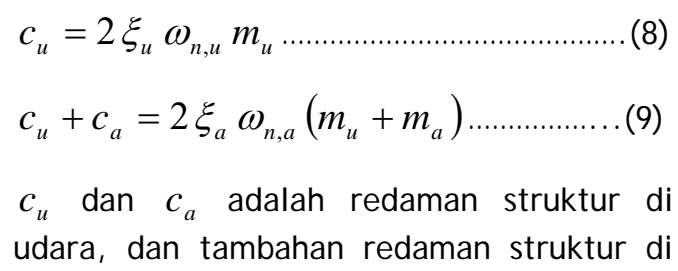


dalam air. $\xi_{u}$ dan $\xi_{a}$ adalah faktor redaman struktur di udara dan di dalam air.

Dari persamaan (5), (6), (8) dan (9) diperoleh ratio redaman struktur di udara dan di dalam air atau disebut added damping factor (ADF)

$$
A D F=\frac{c_{a}}{c_{u}}=\frac{\xi_{a} \omega_{n, u}}{\xi_{u} \omega_{n, a}}-1
$$

\section{METODA PENGUJ IAN}

Pada studi ini respons getaran dari pelat dengan dan tanpa retak di udara dan air diukur dalam rentang frekwensi tertentu dengan frekwensi tertinggi sebesar $1160 \mathrm{~Hz}$. Namun hanya 3(tiga) ragam lentur saja yang akan dilaporkan dalam tulisan ini karena dengan alasan praktis bahwa penulis ingin mefokuskan pada ragam lentur struktur pada frekwensi rendah (dalam hal ini lebih kecil dari $500 \mathrm{~Hz}$ ).

Untuk melakukan uji perilaku dinamis pelat di dalam air, dibuat tangki dengan panjang $1300 \mathrm{~mm}$, lebar $550 \mathrm{~mm}$, dan tinggi $800 \mathrm{~mm}$. Tangki tersebut dilas diatas sebuah platform (meja baja) yang kokoh dan tidak bergetar ketika uji dilakukan. Uji dilakukan di Lab struktur, MUN. Gambar 1 menunjukkan pengaturan peralatan uji. Pada eksperimen ini struktur pelat diuji pada posisi horizontal. Untuk uj i pengaruh rendaman air pada perilaku dinamis pelat, struktur tersebut direndam pada dua level ketinggian yaitu (a). ketinggian air kira kira separuh dari ketebalan pelat. (b). ketinggian air

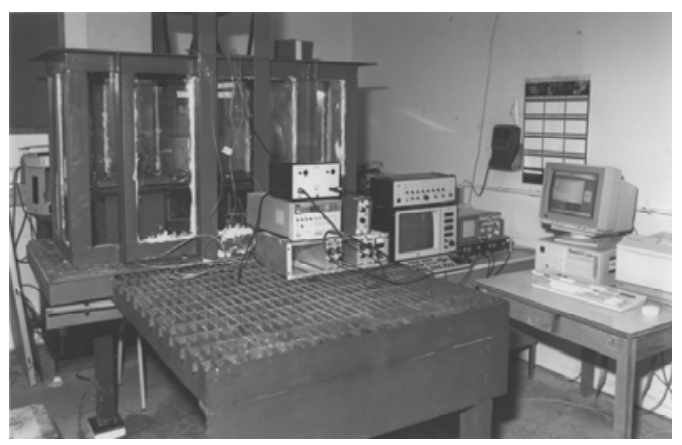

Gambar 1: Pengaturan peralatan untuk eksperimen 230mm diukur dari permukaan pelat bagian atas.

Pelat yang diuji adalah pelat baja berukuran $652 \times 204 \times 9.5 \mathrm{~mm}$. Uji dilakukan dalam dua kondisi yaitu utuh dan terdapat retak berbentuk " $\mathrm{v}$ " pada kedua sisi pelat (lihat Gambar 2). Kedalaman retak sebesar 2×3/32" (2x2,381mm) sedangkan lebar retaknya relatif kecil. Pelat tersebut dijepit salah satu sisi pendeknya dengan blok baja dan dibaut dengan enam buah baut berdiameter $19 \mathrm{~mm}$ sedangkan sisi sisi yang lain dibiarkan bebas.

Pelat digetar dengan menggunakan eksitasi fast sine sweep dengan waktu yang dipilih sehingga diperoleh fungsi respons frekwensi terbaik yang ditunjukkan oleh hasil pengukuran fungsi koherensi (coherence function). 3(tiga) buah strain gage (alat pengukur regangan) dan sebuah akselerometer (alat pengukur percepatan) diletakkan diatas permulaan pelat guna memonitor respons getaran struktur. Posisi sensor (akselerometer dan strain gage), titik eksitasi, serta letak retak ditunjukkan pada Gambar 3. Gaya eksitasi yang diberikan pada struktur dan respons struktur yang diukur melalui sensor sensor tersebut diatas dianalisa dengan menggunakan Dual Channel Analyzer. Fungsi respons frekwensi dan fungsi koherensi diperoleh dari analyzer ini. Selanjutnya paramater modal (frekwensi alamiah, faktor redaman dan bentuk ragam) diperoleh dengan menggunakan program STAR (1990).

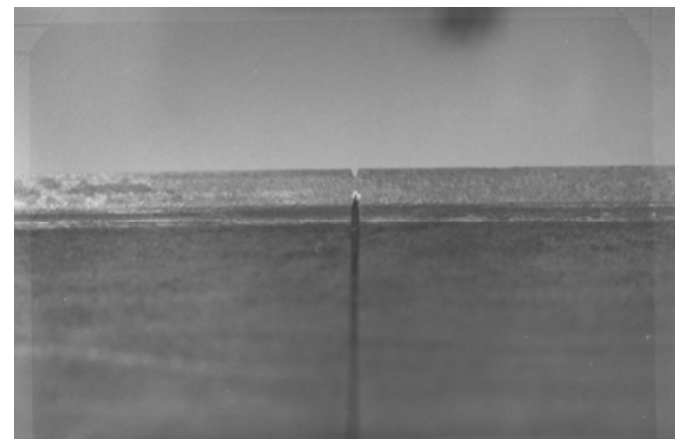

Gambar 2: Bentuk retak pada pelat yang diteliti 


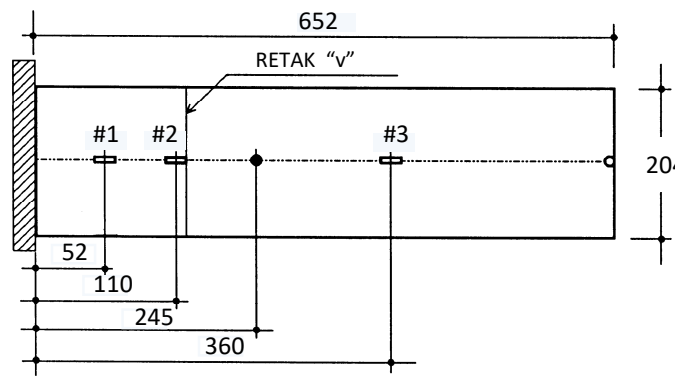

- TITIK EKSITASI

- AKSELEROMETER

๑ STRAIN GAGE

Gambar 3: Letak sensor yang digunakan dalam eksperimen (jarak dalam $\mathrm{mm}$ )

\section{HASIL UJ I DAN DISKUSI}

Fungsi respons frekwensi dari respons regangan di lokasi strain gage \#3 dan akselerometer dari hasil uji pelat utuh di udara ditampilkan pada Gambar 4. Frequency alamiah dan faktor redaman hasil pengukuran selama eksperimen untuk pelat tanpa dan dengan retak ditampilkan pada Gambar 5 dan 6. Seperti telah disebutkan sebelumnya dalam eksperimen ini uji struktur dilakukan di udara (uji \#1), terendam sebagian di dalam air (uj i \#2) dan terendam seluruhnya di dalam air (uji \#3). Dari hasil eksperimen tersebut nyata bahwa frekwensi alamiah struktur menurun akibat rendaman air. Dengan penurunan berkisar antara 20,2\% sampai dengan 40,4\% Akibat retak pada struktur frekwensi alamiah juga turun walau penurunan untuk tiga ragam pertama relatif kecil yaitu kurang dari 1.0 $\%$

Seperti yang diharapkan faktor redaman naik akibat redaman air. Dibandingan faktor redaman di udara, faktor redaman struktur yang terendam sepenuhnya dalam air sekitar maksimum 6.6 kali. Pada kondisi tersebut faktor redaman struktur mengalami kenaikan berkisar antara $18,1 \%$ sampai dengan $55.7 \%$ Akibat retak pada struktur, nilai faktor redaman tidak mempunyai kecenderungan tertentu terutama nilai dari uj i struktur di dalam air. (a). akselerometer

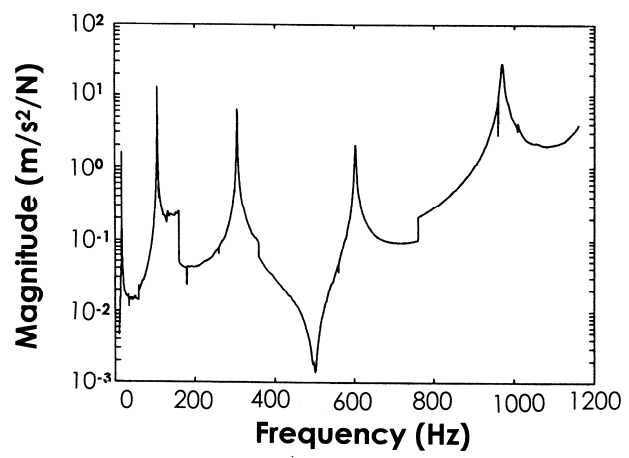

(b). strain gage

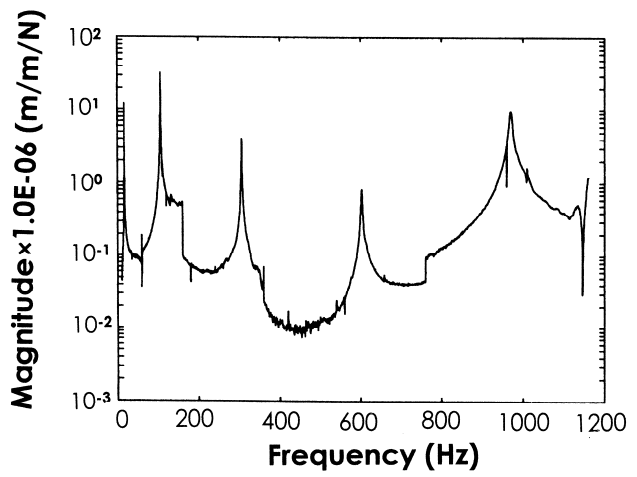

Gambar 4: Fungsi respons frekwensi dari respons (a). akselerometer dan (b). strain gage\# 3.

Bentuk ragam diperoleh dari respons strain gage. Hasil dari pengukuran bentuk ragam yang diperoleh dari respons regangan disajikan pada Tabel 1. Seperti dapat dilihat dari Tabel 1, bentuk ragam struktur yang diuji baik di udara maupun terendam di dalam air relatif tidak berubah. Hasil ini menguatkan hasil eksperimen yang dilakukan oleh Gounaris dan Papadopoulos (1997). Akibat retak pada struktur, perubahan bentuk ragam pada tiga ragam pertama relatif kecil. Hal ini mungkin disebabkan oleh posisi retak struktur sehingga tidak memungkinkan ragam untuk berubah terutama pada frekwensi rendah. 
(a). ragam ke 1

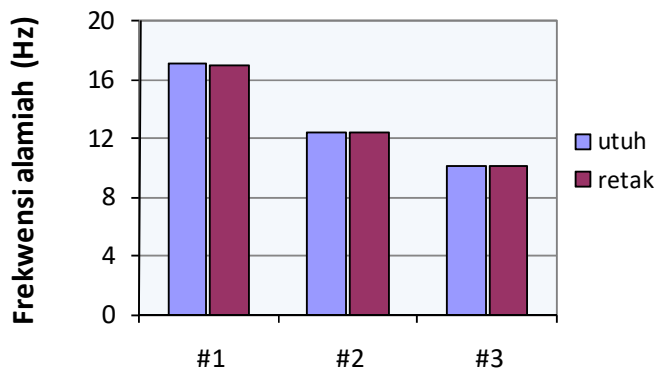

No. Uji

(b). ragam ke 2

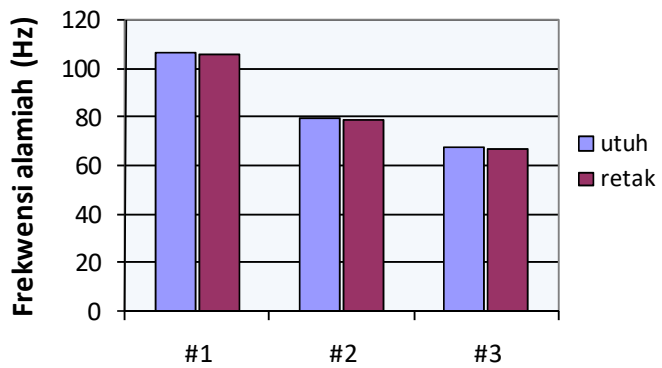

No. Uji

(c). ragam ke 3

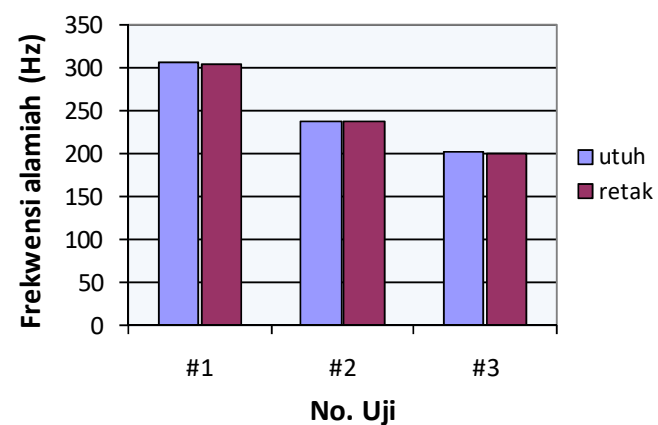

Gambar 5: Frekwensi alamiah struktur utuh dan retak pada uji di udara (\#1), terendam sebagian (\#2) dan terendam seluruhnya dalam air (\#3) untuk tiga ragam pertama. (a). ragam ke 1

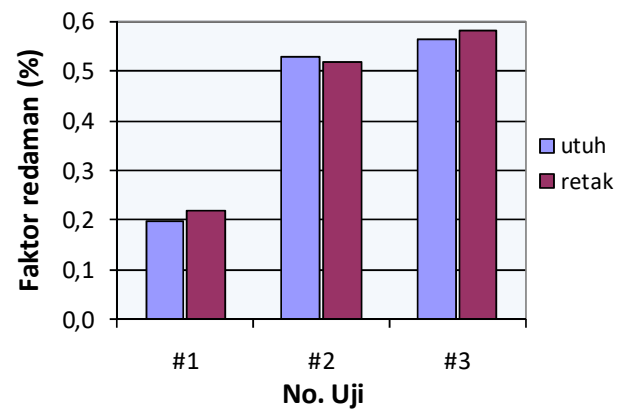

(b). ragam ke 2

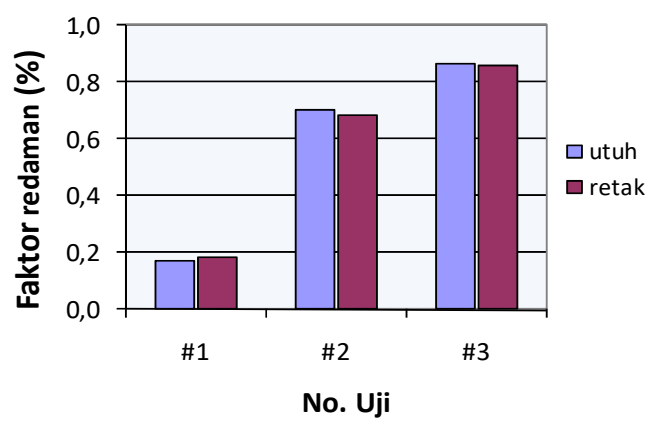

(c). ragam ke 3

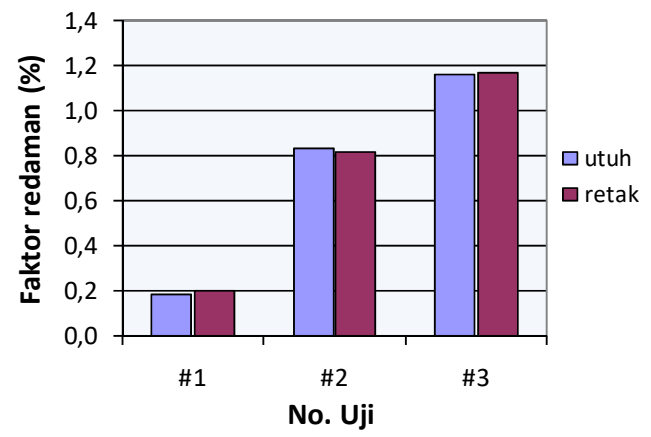

Gambar 6: Faktor redaman struktur utuh dan retak pada uji di udara (\#1), terendam sebagian (\#2) dan terendam seluruhnya (\#3) dalam air untuk tiga ragam pertama. 
Tabel 1: Ragam dari struktur utuh

(a). Struktur di udara

\begin{tabular}{c|ccc}
\hline \multirow{2}{*}{ Ragam } & \multicolumn{3}{|c}{ Nilai di lokasi strain gage } \\
\cline { 2 - 4 } & $\# 1$ & $\# 2$ & $\# 3$ \\
\hline 1 & 1,000 & 0,863 & 0,313 \\
\hline 2 & 0,848 & 0,274 & 1,000 \\
\hline 3 & 1,000 & 0,693 & 0,865 \\
\hline
\end{tabular}

(b). Struktur terendam seluruhnya dalam air

\begin{tabular}{c|ccc}
\hline \multirow{2}{*}{ Ragam } & \multicolumn{3}{|c}{ Nilai di lokasi strain gage } \\
\cline { 2 - 4 } & $\# 1$ & $\# 2$ & $\# 3$ \\
\hline 1 & 1,000 & 0,862 & 0,314 \\
\hline 2 & 0,848 & 0,274 & 1,000 \\
\hline 3 & 1,000 & 0,693 & 0,864 \\
\hline
\end{tabular}

Berdasarkan hasil eksperimen tersebut, nilai added mass dan added damping factor dihitung dengan persamaan (7) dan (10) dan hasilnya disajikan pada Gambar 7 dan 8. Akibat rendaman air, nilai added mass factor pada ragam pertama dari struktur yang diuji lebih dominan (nilainya lebih tinggi) dibandingkan dengan ragam kedua dan ketiga, lihat Gambar 7(a) dan (b). Perbedaan nilai added mass factor antara kondisi struktur utuh dan dan retak tidak signifikan. Hal ini disebabkan perbedaan frekwensi alamiah struktur pada dua kondisi tersebut kecil.

Akibat rendaman air nilai added damping factor naik berkisar antara $41,5 \%$ sampai dengan 108,3\% Nilai faktor ini semakin tinggi untuk ragam yang lebih tinggi. Dengan adanya retak pada struktur nilai added damping factor pada struktur turun, dengan penurunan berkisar antara 4,9\% sampai dengan $13,9 \%$ lihat Gambar $8(a)$ dan 8(b).

\section{KESIMPULAN}

Tulisan ini menyajikan hasil studi eksperimental terhadap struktur kantilever pelat baja elastis yang bergetar di udara, terendam sebagian, dan terendam seluruhnya di dalam air. Pelat tersebut diuj i dalam dua kondisi yaitu utuh dan terdapat retak semetris berbentuk " $\mathrm{v}$ ". Parameter modal dari struktur (frekwensi alamiah, (a). struktur terendam sebagian dalam air

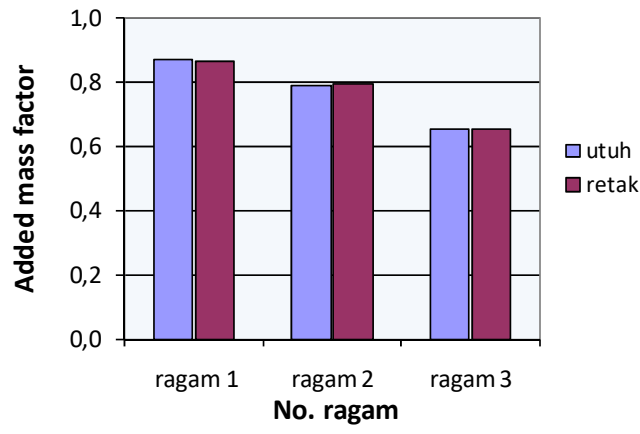

(b). struktur terendam seluruhnya dalam air

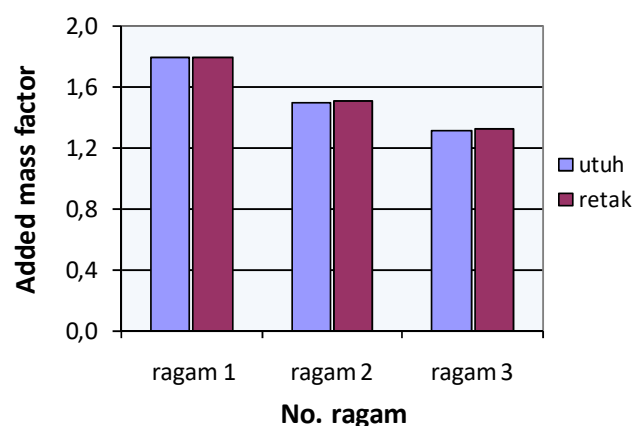

Gambar 7: Added mass factor struktur utuh dan retak pada tiga ragam yang pertama untuk struktur (a) terendam sebagian dan (b) terendam seluruhnya dalam air.

faktor redaman dan bentuk ragam), nilai added mass dan added damping factor dari struktur diperoleh dan dibandingkan guna mengetahui pengaruh redaman air dan retak pada struktur. Dari hasil studi ini dapat disimpulkan:

- Frekwensi alamiah struktur turun akibat rendaman air dengan kenaikan maksimum sebesar 40,4\% Akibat adanya retak, frekwensi alamiah struktur yang diuji turun. Namun penurunannya relatif kecil yaitu kurang dari $1 \%$

- Faktor redaman mengalami kenaikan maksimum sebesar $55,7 \%$ Pengaruh retak pada struktur terhadap nilai faktor redaman tidak berarti. Nilai ini juga tidak mengikuti kecenderungan tertentu (naik atau turun). 
(a) Struktur terendam sebagian dalam air

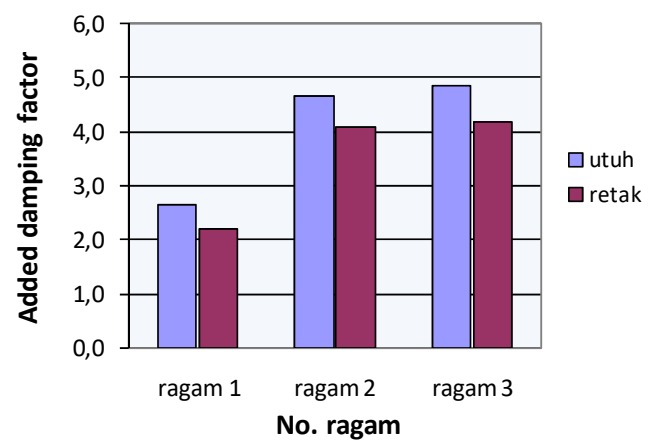

(b) Struktur terendam seluruhnya dalam air

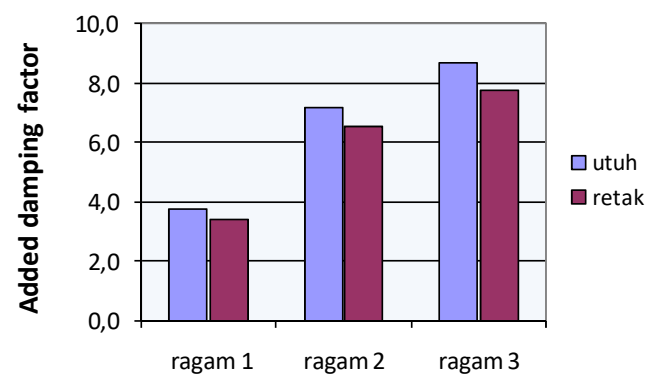

No. ragam

Gambar 8: Added damping factor struktur utuh dan retak pada tiga ragam yang pertama untuk struktur (a) terendam sebagian dan (b) terendam seluruhnya dalam air.

- Bentuk ragam struktur di udara, terendam dalam air (sebagian atau keseluruhan) tidak berubah. Bentuk ragam untuk 3 (tiga) ragam pertama pada struktur dengan retak relatif sama dengan struktur utuh.

- Nilai added mass factor struktur yang dominan terjadi pada ragam pertama. Dalam studi ini, retak pada struktur yang diuji tidak mempengaruhi nilai added mass factor secara berarti.
- Nilai added damping faktor yang paling rendah terjadi pada ragam pertama dengan kecenderungan naik untuk ragam yang lebih tinggi. Akibat rendaman air nilai ini naik berkisar antara $41,5 \%$ sampai dengan 108,3\% Sedang akibat adanya keretakan pada struktur, nilai added damping factor secara konsisten menurun berkisar antara 4,9\% sampai dengan $13,9 \%$ Dengan demikian rendaman air dan retak pada struktur berpengaruh cukup signifikan pada nilai added damping factor.

\section{DAFTAR ACUAN}

De Santo, D.F. 1981. Added Mass and Hydrodynamic Damping of Perforated Plates Vibrating in Water. Journal of Pressure Vessel Technology, 103, 17582.

Gounaris, G.D., dan Papadopoulos, C.A. 1997. Analytical and Experimental Crack Identification of Beam Structures in Air or in Fluid. Computers and Structures, Vol. 65, 633-39.

Haddara, M.R., dan Cao, S. 1996. A Study of the Dynamic Response of Submerged Rectangular Flat Plates. Marine Structures, Vol. 9, 913-33.

Lieb., B.W., Jacal, A.P., and Glasser, R.P., 1989. Added Mass for Plates Partially Submerged in Water, Proceedings of the 7th International Modal Analysis Conference, Orlando, Florida, 453-58.

Maia, N.M.M. dan Silva, J.M.M. 1997. Theoretical and Experimental Modal Analysis. Research Studies Press LTD.

Randall, R. 1985. Modal Analysis of A Cylinder Structure Immersed in Water. Proceedings of the 3rd International Modal Analysis Conference, 670-76.

Star Refererence Manual. 1990. Structural Measurement Systems, 58p. 